\title{
Hazard Level of Dengue Haemorrhagic Fever in Gorontalo Regency: Prediction of Spatial Distribution with AHP-GIS Integration
}

\author{
Tingkat Bahaya Demam Berdarah di Kabupaten Gorontalo: \\ Prediksi Distribusi Spasial dengan Integrasi AHP-SIG
}

\author{
Ririn Pakaya ${ }^{* 1}$, Yanti H. Hano ${ }^{2}$, Muhammad R. Olii ${ }^{3}$ \\ ${ }^{1,2}$ Bagian Ilmu Kesehatan Masyarakat, Universitas Gorontalo, Gorontalo \\ ${ }^{3}$ Bagian Teknik Sipil, Universitas Gorontalo, Gorontalo
}

DOI: 10.24252 /al-sihah.v13i2.21788

Received: 2 July 2021 / In Reviewed: 10 October 2021 / Accepted: 24 December 2021 / Available online: 30 December 2021

(C) The Authors 2021. This is an open access article under the CC BY-NC-SA 4.0 license

\begin{abstract}
Under certain climatic conditions, Aedes aegypti and Aedes albopictus mosquitoes can survive and reproduce optimally so that climate change can significantly change the pattern of disease distribution. This study aimed to model the level of Dengue Haemorrhagic Fever (DHF) hazard in Gorontalo Regency by integrating the Analytical Hierarchy Process (AHP), Geographic Information System (GIS) with climatological and topographic factors. The factors that most influence the level of hazard of DHF are annual rainfall, altitude, and humidity. The results obtained show that Gorontalo Regency is dominated by the hazard level class of 94852.31 ha or $44.25 \%$ and the moderate class area of 82553.37 ha or $38.5 \%$ of the total area of Gorontalo Regency. These results prove that Gorontalo Regency is very at risk of DHF disease. If this is not handled by the government properly, the moderate class will potentially rise to the high class. The prediction model for the DHF hazard level in this study can be made according to local conditions in the research area which have limited data. Changes in climate variables and periodicity that affect the incidence of dengue can be flexibly adapted to this model. The findings from this study provide valuable insights that have the potential to improve mitigation in public health-related interventions.
\end{abstract}

\begin{abstract}
ABSTRAK
Pada kondisi iklim tertentu, nyamuk Ae. aegypti dan Ae. albopictus dapat bertahan dan bereproduksi secara optimal sehingga perubahan iklim dapat mengubah pola sebaran penyakit secara signifikan. penelitian ini bertujuan untuk memodelkan tingkat bahaya Demam Berdarah Dengue (DBD) di Kabupaten Gorontalo dengan mengintegrasikan antara Analytical Hierarchy Process (AHP), Sistem Informasi Geografis (SIG) dengan faktor klimatologi dan topografi. Faktor yang paling berpengaruh terhadap tingkat bahaya DBD adalah hujan tahunan, ketinggian dan kelembaban. Hasil yang diperoleh memperlihatkan bahwa Kabupaten Gorontalo didominasi oleh kelas tingkat bahaya seluas 94852,31 ha atau $44,25 \%$ dan kelas sedang seluas 82553,37 ha atau 38,5\% dari total luas Kabupaten Gorontalo. Hasil ini membuktikan bahwa Kabupaten Gorontalo sangat riskan terhadap penyakit DBD. Jika hal ini, tidak ditangani oleh pemerintah dengan baik, maka kelas sedang berpotensi naik menjadi kelas tinggi. Model prediksi tingkat bahaya DBD dalam penelitian ini dapat dibuat sesuai dengan keadaan lokal di wilayah penelitian yang memiliki keterbatasan data. Perubahan pada variabel dan periodesitas iklim berpengaruh pada kejadian dengue secara fleksibel dapat disesuaikan dengan model ini. Temuan dari penelitian ini memberikan wawasan berharga yang berpotensi meningkatkan mitigasi dalam penanganan surveilans kesehatan masyarakat maupun surveilans epidemiologi.
\end{abstract}

\section{GRAPHICAL ABSTRACT}

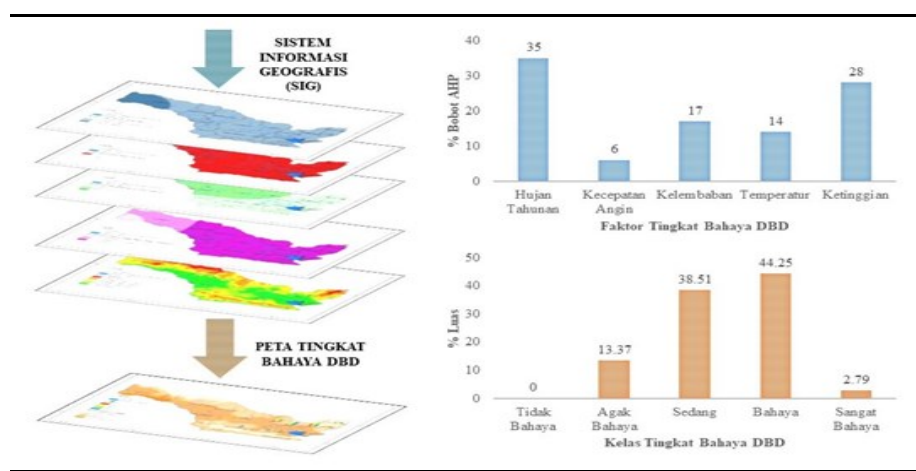

\section{Keyword}

analytical hierarchy process; dengue haemorrhagic fever; gis; gorontalo regency; hazard level

Kata Kunci:

analytical hierarchy process; demam berdarah; kabupaten gorontalo; sig; tingkat bahaya

* Correspondence

Lingkungan 2, Hatuo, Limboto, Kab. Gorontalo, Gorontalo, 96213

Email: ririn.pakaya@mail.ugm.ac.id 


\section{PENDAHULUAN}

Demam Berdarah Dengue (DBD) merupakan penyakit yang disebabkan oleh virus dengue yang ditularkan melalui gigitan nyamuk Aedes aegypti dan Aedes albopictus yang sebelumnya telah terinfeksi oleh virus dengue dari penderita DBD lainnya. Pada awalnya, kasus DBD ditemukan antara 1779-1780 di Benua Afrika, Asia, dan Amerika Utara. Dalam lima puluh tahun terakhir, peningkatan jumlah penduduk, mobilitas penduduk, dan perubahan perilaku masyarakat di hampir seluruh dunia menyebabkan penyebaran DBD mengalami peningkatan 30 kali lipat. Kurang lebih 100 juta kasus DBD terjadi setiap tahunnya di negara-negara endemis (WHO Regional Publication SEARO, 2011), dimana jumlah kasus tertinggi di dunia terjadi di Asia Tenggara, yaitu Indonesia (Harapan et al., 2019).

DBD merupakan salah satu masalah kesehatan masyarakat utama di Indonesia sejak ditemukan pertama kali di Jakarta dan Surabaya pada tahun 1968. Saat ini, semua provinsi di Indonesia telah melaporkan kejadian DBD dan beberapa wilayah menjadi kejadian luar biasa (KLB). Pada tahun 2019, terjadi peningkatan 65.602 kasus menjadi 138.127 kasus jika dibandingkan dengan tahun sebelumnya. Jumlah kabupaten/kota terjangkit pada tahun 2019 sebanyak 481 atau 93,58\% dari seluruh kabupaten/kota yang ada di Indonesia dan dari 514 kabupaten/kota terdapat 320 kabupaten/ kota $(62,26 \%)$ yang sudah mencapai IR DBD $<49$ per 100.000 penduduk (Kementerian Kesehatan RI, 2020).

Perubahan iklim adalah fenomena global transformasi iklim yang ditandai dengan perubahan curah hujan, suhu, pola angin, kelembaban, dan ukuran iklim lainnya yang terjadi selama beberapa dekade atau lebih. Variasi faktor iklim tersebut dapat berdampak pada kejadian penyakit DBD. Faktor iklim memainkan peran penting dalam menularkan penyakit demam berdarah. Beberapa peneliti menemukan bahwa curah hujan dapat mempengaruhi transportasi dan penyebaran agen infeksi sementara suhu merangsang pertumbuhan dan kelangsungan hidup mereka (Sulekan et al., 2021). Secara umum, kondisi iklim memiliki pengaruh paling penting pada siklus hidup demam berdarah. Fluktuasi suhu secara signifikan dapat mempengaruhi penularan dengue dan populasi nyamuk Aedes (Tran et al., 2013). Ukuran dan kepadatan populasi larva juga akan ditentukan oleh jumlah dan pola curah hujan (Ewing et al., 2016). Kondisi lingkungan seperti suhu hangat dan kelembaban tinggi akan mendorong pertumbuhan populasi larva. Demam berdarah yang tercatat di negaranegara Asia Pasifik seperti Indonesia, Thailand, Singapura juga terkait dengan suhu, kelembaban relatif, dan curah hujan (Sulekan et al., 2021). Semua perubahan ini menunjukkan bahwa kondisi iklim memiliki peran penting dalam penularan penyakit demam berdarah (Caldwell et al., 2021; Campbell et al., 2015; Ewing et al., 2016; Nuraini et al., 2021; Sulekan et al., 2021).

Provinsi Gorontalo merupakan provinsi keempat dengan IR tertinggi pada tahun 2019 yaitu sebesar 101,53\% per 100.000 penduduk dengan CFR sebesar 1,88. Kabupaten Gorontalo merupakan ka- 
bupaten/kota dengan kejadian DBD tertinggi dari 5 kabupaten lainnya, yaitu Kota Gorontalo, Bone Bolango, Pohuwato, Boalemo dan Gorontalo Utara. Kejadian DBD dari tahun 2017, 2018, 2019, dan 2020 di Kabupaten Gorontalo masingmasing berjumlah 151, 244, 394, 338 kejadian. Dalam mengatasi bencana DBD tidak hanya dapat dilakukan dengan tindakan preventif seperti 3M (menguras, menutup, dan mengubur) yang selama ini telah dijalankan, namun juga diperlukan adanya tindakan mitigasi, yaitu serangkaian upaya untuk mengurangi risiko bencana, baik melalui pembangunan fisik dan nonfisik (Idriani et al., 2019). Salah satu upaya mitigasi adalah pemetaan distribusi spasial tingkat bahaya DBD di Kabupaten Gorontalo. Hal ini dapat mencegah penyebaran DBD dalam hal ruang dan waktu dengan database spasial, penerapan statistik spasial dan mengaitkan informasi tersebut dengan faktor lingkungan di suatu wilayah.

Penggunaan analisis spasial dalam sistem informasi geografis (SIG) dalam dunia kesehatan menjadi salah satu teknik utama untuk mengidentifikasi asosiasi spasial dari beberapa faktor dan telah digunakan oleh beberapa peneliti di seluruh dunia (Franch-Pardo et al., 2020; Murad, 2018; Musa et al., 2013; Nakhapakorn \& Tripathi, 2005; Saran et al., 2020; Sulistyawati, 2020). Integrasi AHP-SIG juga telah banyak diterapkan dalam menganalisis distribusi spasial wahab penyakit, seperti DBD (Ajim Ali \& Ahmad, 2018; Nazri Che et al., 2016), Malaria (Bhatt \& Joshi, 2014; Rakotoarison et al., 2020), virus zika (Li et al., 2017). Nakhapakorn \& Tripathi
(2005) melakukan penelitian spasial SIG untuk mengeksplorasi pengaruh faktor lingkungan fisik terhadap kejadian DBD di Provinsi Sukhothai, Thailand dengan menggunakan metode nilai informasi yang menunjukkan bahwa kawasan terbangun memiliki pengaruh paling besar terhadap kejadian DBD dibandingkan dengan tutupan lahan lainnya. kelas penggunaan lahan. Dom et al. (2016) menganalisis tingkat risiko dengan DBD mengintegrasikan antara AHP dan SIG dan menemukan Faktor yang paling berpengaruh ditemukan adalah jenis perumahan, kepadatan penduduk, penggunaan lahan dan ketinggian. SIG dan metode analisis spasial dapat diterapkan untuk meningkatkan strategi surveilans DBD dan penyakit menular lainnya dalam upaya mendorong tindakan pencegahan dan pengendalian. Ajim Ali \& Ahmad (2018) menggunakan AHP-SIG untuk pemetaan risiko DBD di Kolkata Municipal Corporation, Benggala Barat, India dan menemukan faktor yang paling berpengaruh adalah kepadatan rumah tangga, daerah genangan air, suhu permukaan lahan, kepadatan penduduk, ketinggian lahan dan tata guna lahan penutupan lahan. Tsheten et al. (2021) menggunakan Analisis Keputusan Multikriteria yang terintegrasi dengan SIG untuk mengidentifikasi daerah-daerah yang rentan terjadi penularan demam berdarah paling mungkin terjadi di Bhutan selama musim-musim tertentu.

Dalam penentuan tingkat resiko bencana alam atau non alam di Indonesia menggunakan tiga komponen yang diperlukan, yaitu hazard (bahaya), vulnerability 
(kerentanan) dan capacity (kapasitas). Penentuan ketiga komponen tersebut umumnya hanya digunakan untuk bencana alam sehingga penelitian di Indonesia terkait bencana non alam masih sangat terbatas. Penyakit DBD merupakan bencana non alam yang sampai saat ini model risiko DBD belum dibuat oleh pemerintah atau pihak yang berkepentingan. Oleh karena itu, pada penelitian ini mencoba untuk membuat model salah satu komponen risiko DBD, yaitu model hazard (bahaya) untuk DBD di Kabupaten Gorontalo dengan mengintegrasikan antara AHP dan SIG dengan faktor klimatologi dan topografi.

\section{METODE PENELITIAN}

Kabupaten Gorontalo merupakan kabupaten yang berada di tengah Provinsi Gorontalo dengan letak astronomis antara $0^{\circ} 28^{\prime} 23.22$ "- $0^{\circ} 55^{\prime} 45.08^{\prime \prime}$ LU dan $122^{\circ} 14^{\prime} 43.69^{\prime \prime}$ dan $123^{\circ} 4^{\prime} 48.27^{\prime \prime}$ BT. Kabupaten Gorontalo berbatasan dengan Kabupaten Gorontalo Utara di sebelah utara, berbatasan dengan Teluk Tomini di sebelah selatan, berbatasan dengan Kabupaten Boalemo di sebelah barat dan berbatasan dengan Kabupaten Bone Bolango dan Kota Gorontalo di sebelah timur. Secara geografis mempunyai luas $2.125,47 \mathrm{~km}^{2}$ atau $15,55 \%$ dari luas Provinsi Gorontalo. Kabupaten Gorontalo terbagi menjadi 19 kecamatan dan terdiri dari 206 desa/kelurahan. Kecamatan dengan luas terbesar adalah Kecamatan Asparaga dan terkecil adalah Kecamatan Tilango.

Dalam penelitian ini, semua peta faktor yang mempengaruhi tingkat bahaya DBD berdasarkan model raster. Digital Ele- vation Model (DEM) diunduh dari https:// earthexplorer.usgs.gov/ yang digunakan untuk menggambarkan distribusi spasial ketinggian (elevasi) dengan ukuran grid 30 $\times 30 \mathrm{~m}^{2}$. Data kecepatan angin harian $(\mathrm{m} /$ detik), kelembaban harian (\%), hujan harian (mm/hari), dan temperatur harian $\left({ }^{\circ} \mathrm{C}\right)$ diunduh dari https://power.larc.nasa.gov/ dengan ukuran grid $0,5^{\circ} \times 0,5^{\circ}$. Batas administrasi kelurahan, kecamatan, dan Kabupaten Gorontalo diunduh dari https:// gadm.org/data.html/ berbentuk shapefile. Kejadian DBD tahun 2017-2020 di Kabupaten Gorontalo diperoleh dari Dinas Kesehatan Kabupaten Gorontalo berbentuk attribute table.

Tujuan penelitian adalah memodelkan tingkat bahaya DBD dengan 5 kriteria yang berpengaruh terhadap model tersebut, hujan, suhu, kelembaban, kecepatan angin, dan elevasi. Hujan sangat berpengaruh terhadap kelembaban nisbi udara jumlah tempat perkembangan vektor. Kemungkinan kelangsungan hidup nyamuk yang terinfeksi pada musim penghujan akan meningkat karena suhu udara dan kelembaban udara selama musim penghujan sangat cocok untuk kelangsungan hidup nyamuk dewasa (Caldwell et al., 2021; Campbell et al., 2015; Nuraini et al., 2021; Sulekan et al., 2021). Lokasi penelitian didominasi oleh hujan total tahunan rerata $2200 \mathrm{~mm} /$ tahun $2300 \mathrm{~mm} /$ tahun seluas $188.570,61$ ha atau $87,98 \%$ dari total luas Kabupaten Gorontalo (Gambar 1).

Suhu memiliki pengaruh penting dalam replikasi virus, ketahanan hidup, dan masa infektif pada nyamuk dewasa. Suhu pada $25-30^{\circ} \mathrm{C}$ adalah kondisi yang tepat 


\section{Gambar 1}

Faktor yang Mempengaruhi Tingkat Bahaya DBD di Kabupaten Gorontalo
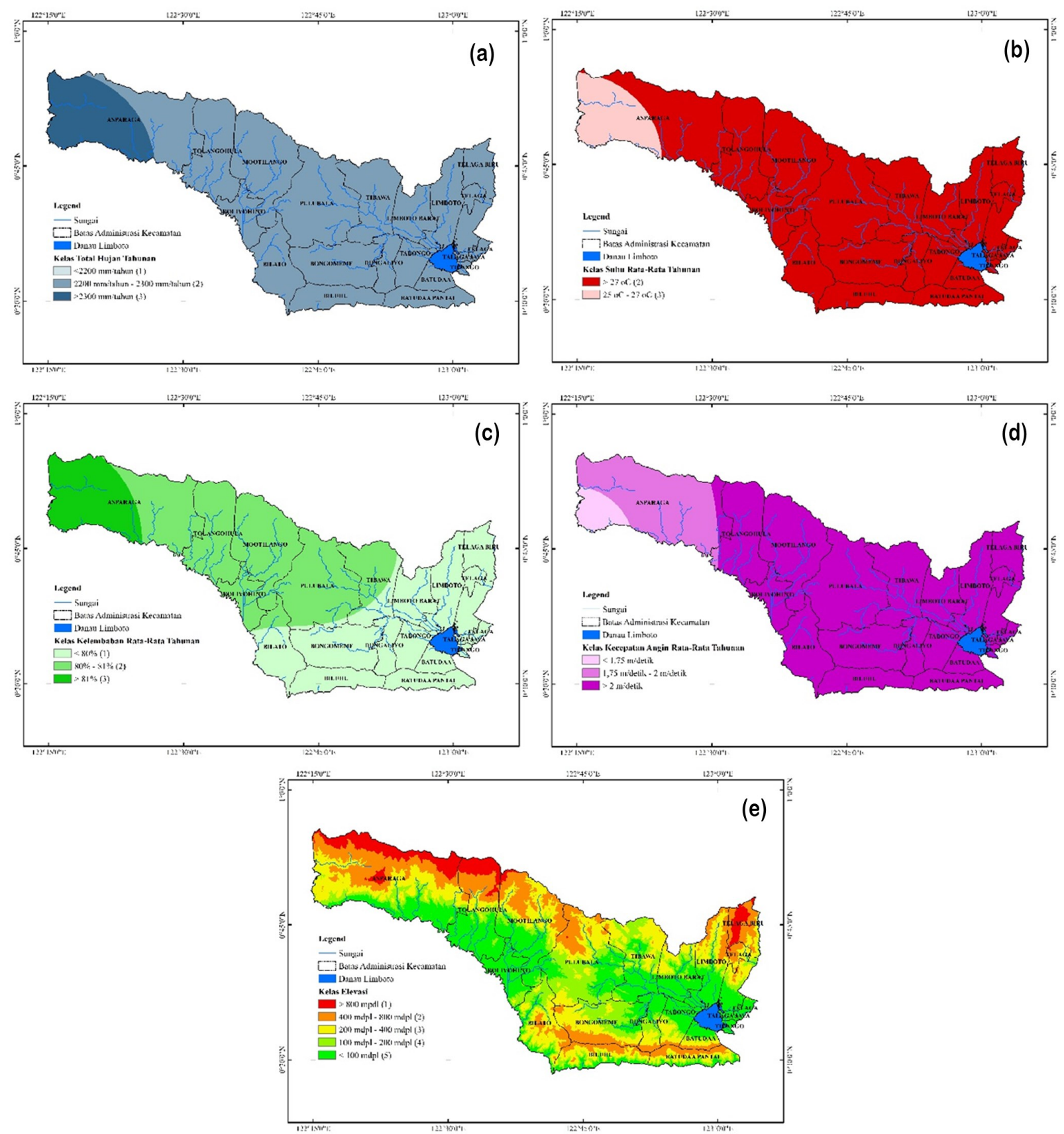

Note: (a) Kelas Hujan Total Tahunan; (b) Kelas Suhu Rata-Rata Tahunan; (c) Kelas Kelembaban Rata-Rata Tahunan; (d) Kelas Kecepatan Angin Rata-Rata Tahunan; (e) Kelas Ketinggian/Elevasi

untuk Ae. aegypti bereproduksi dan meletakkan telurnya (Caldwell et al., 2021). Di beberapa wilayah di dunia dalam empat dekade terakhir mengalami kenaikan suhu secara global sehingga berpotensi ter- jadinya penularan DBD (WHO, 2018). Inkubasi ekstrinsik virus dalam tubuh nyamuk bergantung pada suhu (Tjaden et al., 2013). Hampir Sebagian besar wilayah atau lebih dari 90\% Kabupaten Gorontalo mem- 
Tabel 1

Perbandingan Berpasangan antara Faktor Bahaya DBD Kabupaten Gorontalo

\begin{tabular}{lccccc}
\hline Faktor Bahaya DBD & Hujan & $\begin{array}{c}\text { Kecepatan } \\
\text { Angin }\end{array}$ & Kelembaban & Suhu & Ketinggian \\
\hline Hujan & 1,00 & 5,00 & 2,00 & 2,00 & 2,00 \\
Kecepatan Angin & 0,20 & 1,00 & 0,33 & 0,33 & 0,25 \\
Kelembaban & 0,50 & 3,00 & 1,00 & 2,00 & 0,33 \\
Suhu & 0,50 & 3,00 & 0,50 & 1,00 & 0,50 \\
Ketinggian & 0,50 & 4,00 & 3,00 & 2,00 & 1,00 \\
\hline \multicolumn{1}{c}{ Total } & 2,70 & 16,00 & 6,83 & 7,33 & 4,08 \\
\hline
\end{tabular}

iliki suhu rata-rata di atas $27^{\circ} \mathrm{C}$ yang sesuai dengan Ae. aegypti bereproduksi dan meletakkan telurnya (Gambar 1) .

Kelembaban memiliki peranan penting dalam kebiasaan menggigit, waktu istirahat, dan kelangsungan hidup (survival rate) nyamuk. Umur nyamuk lebih pendek jika berada pada kondisi kelembaban yang rendah sehingga membatasi siklus perkembangan parasit dalam tubuh nyamuk (Nuraini et al., 2021; Salim \& Syairaji, 2020). Lebih dari $80 \%$ wilayah penelitian didominasi oleh kelembaban rerata lebih dari $>80 \%$ (Gambar 1) sehingga potensi umur nyamuk lebih panjang dan berpotensi meningkatkan sebaran penyakit DBD.

Kecepatan angin berkaitan erat dengan pola distribusi vektor nyamuk secara pasif dan daya terbang nyamuk. Kecepatan angin $25-31 \mathrm{mil} / \mathrm{jam}$ atau $11-14 \mathrm{~m} /$ detik akan mengganggu kemampuan terbang nyamuk. Jarak terbang nyamuk (flight range) dapat diperpendek atau diperpanjang tergantung arah angin. Rata-rata umur nyamuk betina sekitar 8-15 hari dan dapat terbang rata-rata $30-50 \mathrm{~m}$ per hari. Hal ini menunjukkan bahwa nyamuk betina secara umum mampu bergerak pada kisaran 240 - 600 m selama hidupnya (Verdonschot
\& Besse-Lototskaya, 2014). Oleh karena itu, potensi nyamuk terbang lebih jauh dan lebih tinggi jika mendapat bantuan angin di lokasi penelitian yang didominasi dengan kecepatan angin $>2 \mathrm{~m} /$ detik (Gambar 1).

Elevasi pada 0-500 mdpl menyebabkan Nyamuk Ae. aegypti memiliki daya hidup yang tinggi (Tamengkel et al., 2020). Lokasi penelitian ini dibagi menjadi lima kelas ketinggian, yaitu $<100$ mdpl, 100 mdpl - 200 mdpl, 200 mdpl - 400 mdpl, 400 mdpl - 800 mdpl, dan $>800 \mathrm{mdpl}$, dimana didominasi oleh ketinggian $<100 \mathrm{mdpl}$ dengan luas $64.669,59$ ha atau $30,17 \%$ dari total luas wilayah (Gambar 1 dan Tabel 3. Ketinggian $<100$ mdpl Sebagian berada di tengah Kabupaten Gorontalo yang merupakan wilayah pemukiman dan padat penduduk.

Matriks perbandingan berpasangan dengan skala 1 sampai 9 (Tabel 1) antara faktor bahaya DBD yang menggambarkan kontribusi relatif atau pengaruh setiap faktor terhadap tingkat bahaya DBD atau kriteria yang setingkat di atasnya (Tabel 2).

Uji konsistensi perbandingan berdasarkan Consistency Ratio (CR). Agar perbandingan konsisten, dan dengan demikian dapat diterima, $C R$ harus kurang dari 0,1. 


\section{Gambar 2}

Peta Distribusi Spasial Tingkat Bahaya DBD di Kabupaten Gorontalo

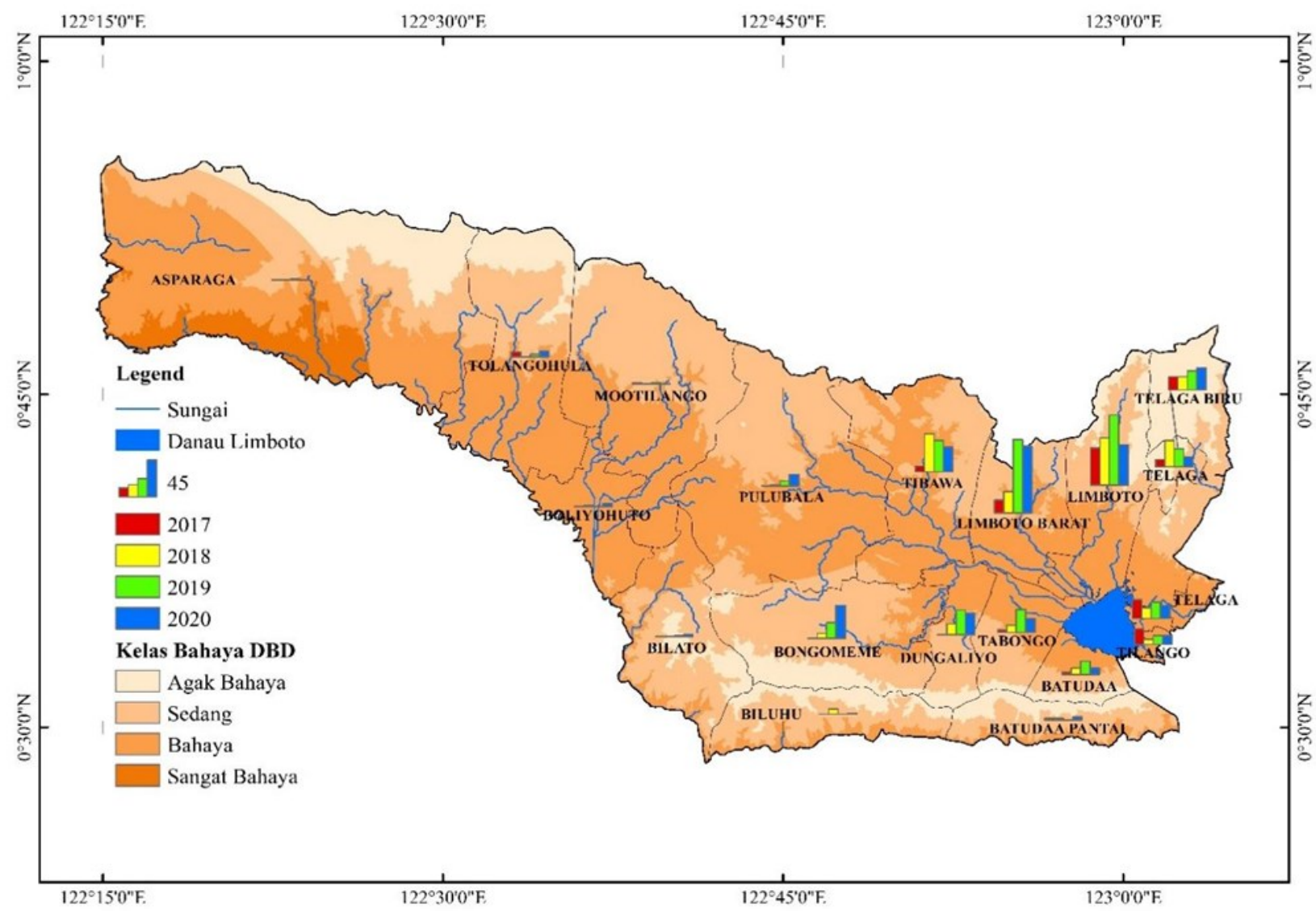

Oleh karena itu, $C R$ adalah indeks numerik untuk menguji konsistensi matriks perbandingan berpasangan dan didefinisikan sebagai berikut:

$$
C R=\frac{C I}{R I}
$$

dimana $C R$ adalah consistency ratio, CI adalah consistency index, dan RI adalah random index (Saaty, 2008). Nilai CI dihitung sebagai berikut:

$$
C I=\frac{\lambda_{\max }-n}{n-1}
$$

dimana $\lambda_{\max }$ adalah nilai eigen maksimum dari matriks perbandingan dan $n$ adalah jumlah kriteria.

Pada penelitian ini, jumlah kriteria adalah 5; $\lambda_{\max }$ adalah 5,21; $C I$ adalah 0.05;
$R I$ adalah 1,12, dan $C R$ adalah 0,046 (4,6\%). Pembobotan untuk setiap faktor yang mempengaruhi tingkat bahaya DBD. Dalam hal ini, setiap bobot faktor dapat dilihat pada Tabel 1 yang digunakan sebagai dasar menyusun Persamaan 3 .

$$
H_{D B D}=0,35 R \times 0,28 E \times 0,17 H \times 0,14 T \times 0,06 S
$$

dimana $H_{D B D}$ adalah bahaya DBD; $R$ adalah bobot kelas total hujan tahunan, $E$ adalah bobot kelas elevasi, $H$ adalah bobot kelas kelembaban rata-rata; $T$ adalah bobot kelas suhu udara rata-rata; dan $S$ adalah bobot kelas kecepatan angin rata-rata.

Penelitian ini tidak melibatkan manusia secara langsung, namun penelitian ini memiliki izin etik yang dikeluarkan 
Tabel 2

Pembobotan Faktor Bahaya DBD Kabupaten Gorontalo

\begin{tabular}{lccccccc}
\hline $\begin{array}{c}\text { Faktor } \\
\text { Bahaya DBD }\end{array}$ & $\begin{array}{c}\text { Hujan } \\
\text { Tahunan }\end{array}$ & $\begin{array}{c}\text { Kecepatan } \\
\text { Angin }\end{array}$ & $\begin{array}{c}\text { Kelemba- } \\
\text { ban }\end{array}$ & $\begin{array}{c}\text { Tempera- } \\
\text { tur }\end{array}$ & $\begin{array}{c}\text { Keting- } \\
\text { gian }\end{array}$ & $\begin{array}{c}\text { Jumlah } \\
\text { Priori- } \\
\text { tas }\end{array}$ \\
\hline Hujan Tahunan & 0,37 & 0,31 & 0,29 & 0,27 & 0,49 & 1,74 & 0,35 \\
Kecepatan Angin & 0,07 & 0,06 & 0,05 & 0,05 & 0,06 & 0,29 & 0,06 \\
Kelembaban & 0,19 & 0,19 & 0,15 & 0,27 & 0,08 & 0,87 & 0,17 \\
Temperatur & 0,19 & 0,19 & 0,07 & 0,14 & 0,12 & 0,70 & 0,14 \\
Ketinggian & 0,19 & 0,25 & 0,44 & 0,27 & 0,24 & 1,39 & 0,28 \\
\hline \multicolumn{1}{c}{ Total } & 1,00 & 1,00 & 1,00 & 1,00 & 1,00 & 5,00 & 1,00 \\
\hline
\end{tabular}

oleh Lembaga Penelitian Universitas Kadiri dengan Nomor Registrasi 004/25/V/EC/ KEP/UNIK/2021.

\section{HASIL PENELITIAN}

Analisis distribusi spasial tingkat bahaya DBD di Kabupaten Gorontalo menggunakan empat faktor klimatologi (hujan, kelembaban, suhu, kecepatan angin) dan satu faktor topografi (elevasi). Kelima faktor tersebut selanjutnya dilakukan tumpang susun (overlay) untuk memperoleh peta distribusi spasial tingkat bahaya DBD yang diklasifikasikan menjadi lima kelas bahaya, yaitu tidak bahaya, agak bahaya, sedang, bahaya dan sangat bahaya (Gambar 2). Warna jingga terang menggambarkan tingkat bahaya DBD rendah dan semakin gelap menggambarkan tingkat bahaya DBD semakin tinggi. Gambar 2 menunjukkan tingkat bahaya DBD berada di bagian tengah Kabupaten Gorontalo yang merupakan wilayah yang memiliki elevasi yang rendah dan merupakan pusat dari beberapa kecamatan. Tingkat sangat bahaya hanya terdistribusi di sebelah barat Kabupaten Gorontalo karena memiliki kondisi iklim yang berpotensi berkembangnya dengue. Apabila dibandingkan antara distribusi spasial tingkat bahaya DBD dan kejadian DBD periode 2017-2020 menunjukkan bahwa wilayah di sebelah timur Kabupaten Gorontalo memiliki tingkat kejadian DBD yang tinggi, terutama wilayah yang didominasi kelas bahaya, seperti Tibawa, Limboto, Limboto Barat, Telaga, Telaga Biru dan Tilango.

Tabel 3 menunjukkan bahwa Kabupaten Gorontalo didominasi oleh kelas bahaya seluas $94.852,31$ ha atau $44,25 \%$ dari total luas Kabupaten Gorontalo. Hasil ini membuktikan bahwa Kabupaten Gorontalo sangat riskan terhadap penyakit DBD. Sedangkan kelas sedang berada di peringkat kedua tertinggi seluas $82.553,37$ ha atau $38,5 \%$ dari total luas Kabupaten Gorontalo. Jika hal ini, tidak ditangani oleh pemerintah dengan baik, maka kelas bahaya sedang berpotensi naik menjadi kelas bahaya.

\section{PEMBAHASAN}

Pengkajian bencana wabah DBD merupakan sebuah pendekatan untuk memperlihatkan potensi dampak negatif yang mungkin timbul akibat suatu potensi bencana yang ada. Berdasarkan Peraturan Kepala Badan Nasional Penanggulangan 
Tabel 3

Distribusi Spasial Tingkat Bahaya DBD Kabupaten Gorontalo

\begin{tabular}{lccc}
\hline \multicolumn{1}{c}{ Kelas Bahaya DBD } & Range Bobot & $\begin{array}{c}\text { Luas } \\
(\mathrm{Ha})\end{array}$ & $\begin{array}{c}\% \\
\text { Luas }\end{array}$ \\
\hline Tidak Bahaya & $1,000-1,511$ & - & - \\
Agak Bahaya & $1,511-2,023$ & $28.654,04$ & 13,37 \\
Sedang & $2,023-2,534$ & $82.553,37$ & 38,51 \\
Bahaya & $2,534-3,045$ & $94.852,31$ & 44,25 \\
Sangat Bahaya & $3,045-3,557$ & $59.86,661$ & 2,79 \\
Danau Limboto & - & $2.295,54$ & 1,07 \\
\hline \multicolumn{1}{c}{ Total } & & $214.341,93$ & 100 \\
\hline \multicolumn{1}{c}{} \\
\hline
\end{tabular}

Bencana No. 02 Tahun 2012 tentang Pedoman Umum Pengkajian Risiko Bencana, potensi dampak negatif terhadap suatu bencana dihitung dengan mempertimbangkan 3 faktor, yaitu tingkat Bahaya/ Hazard; Kerentanan/Vulnerability, dan Kapasitas/Capacity yang berisiko terhadap wabah penyakit. Beberapa penelitian di dunia menyamakan antara ketiga faktor menjadi tingkat risiko saja seperti Ali \& Ahmad (2018), Bhatt \& Joshi (2014), Dom et al. (2016), Li et al. (2017), dan Rakotoarison et al. (2020). Penelitian ini berfokus kepada model prediksi tingkat bahaya/hazard sehingga peluang untuk penelitian terkait kerentanan/vulnerability DBD, kapasitas/vapacity DBD dan risiko/ risk DBD masih dapat dilakukan di masa yang datang.

DBD sangat bergantung pada kondisi vektor yang menularkannya, sebagaimana penyakit menular yang disebabkan oleh vektor yang lain. Vektor nyamuk memiliki kelangsungan hidup dan perkembangbiakan yang tinggi pada keadaan iklim tertentu sehingga perubahan iklim pada suatu wilayah dapat mengubah pola distribusi penyakit secara signifikan. DBD ber- gantung pada musim yang berkorelasi dengan suhu yang hangat dan lembab. Kelembaban, suhu, evaporasi, kecepatan angin, dan lama penyinaran matahari merupakan faktor iklim yang paling berpengaruh pada sebaran penyakit menular melalui vektor (Caldwell et al., 2021; Campbell et al., 2015; Nuraini et al., 2021; Salim \& Syairaji, 2020; Sulekan et al., 2021). Perubahan iklim terhadap penyakit menular melalui vektor tidak berpengaruh secara langsung tetapi berpengaruh pada jumlah dan kelangsungan hidup nyamuk. Para peneliti sangat membutuhkan informasi mengenai kondisi iklim untuk memprediksi tren penyakit menular melalui vektor terutama DBD di masa yang akan datang (WHO, 2018).

Kemungkinan migrasi dan ketahanan hidup nyamuk akibat kenaikan suhu global menyebabkan wilayah yang awalnya wilayah non-endemik berubah menjadi wilayah endemik (Stocker et al., 2013; Murray et al., 2013). Kesesuaian dan kesamaan iklim di daerah non-endemik dengan wilayah endemik DBD karena efek dari perubahan iklim (climate change) menyebabkan vektor nyamuk dapat bertahan 
hidup di daerah non-endemik di masa yang akan datang (Campbell et al., 2015).

Periode epidemi sangat berkorelasi dengan kelembaban yang tinggi di musim penghujan. Hal ini dapat mempersingkat meningkatkan aktivitas vektor dalam menggigit dan masa inkubasi nyamuk (Nuraini et al., 2021; Salim \& Syairaji, 2020). Kelembaban berpengaruh terhadap keaktifan nyamuk dalam menggigit manusia. Jika kelembaban rendah menyebabkan nyamuk mengalami dehidrasi sehingga nyamuk lebih banyak mencari makan untuk mengatasi dehidrasi tersebut. Nyamuk yang berada pada suhu tinggi dan kelembaban rendah akan menghasilkan telur dua kali lipat lebih banyak daripada suhu rendah dengan kelembaban yang tinggi (Caldwell et al., 2021; Reinhold et al., 2018). Xu et al. (2017) menyebutkan bahwa kelembaban berbanding lurus dengan persentase jumlah telur Ae. aegypti yang menetas.

Kecepatan angin berasosiasi dengan dua hal, yaitu suhu udara dan pemberantasan nyamuk dengan cara fogging (pengasapan) (Sulekan et al., 2021). Daya jelajah nyamuk Ae. Aegypti bergantung pada kecepatan angin. Apabila jelajah nyamuk semakin luas kemungkinan untuk mengalami kontak dengan manusia semakin tinggi (Dom et al., 2016). Oleh karena itu, kelangsungan hidup dan masa reproduksi nyamuk semakin tinggi. Secara kualitatif menunjukkan bahwa kapasitas terbang dipengaruhi oleh struktur lanskap, kondisi meteorologi (kecepatan angin, suhu, kelembaban, dan pencahayaan), dan fisiologi spesies (energi yang tersedia untuk terbang) (Verdonschot \& Besse-Lototskaya, 2014).
Di negara-negara non-tropis, pada musim panas kejadian DBD semakin meningkat, walaupun masih ditemukan juga kejadian DBD secara sporadis terjadi pada musim dingin. Di negara-negara tropis, epidemi DBD lebih sering terjadi pada beberapa minggu setelah musim hujan, seperti Indonesia, Malaysia, dan Filipina. Sedangkan epidemi DBD mencapai puncak tertinggi sebulan sebelum curah hujan mencapai puncak tertinggi dan akan menurun sejalan dengan menurunnya curah hujan (Caldwell et al., 2021; Campbell et al., 2015; Nuraini et al., 2021; Salim \& Syairaji, 2020; Sulekan et al., 2021). Selain itu, jumlah hari hujan menjadi faktor penyebab munculnya tempat perkembangbiakan nyamuk, dimana waktu hidup larva dan kepompong berada di air (breeding place), serta mempengaruhi kelembaban dan suhu di suatu wilayah (WHO, 2018).

Ketinggian tempat dapat mempengaruhi sebaran vektor DBD yaitu nyamuk Aedes aegypti (Ramos et al., 2020). Hendri et al. (2015) menunjukkan bahwa vektor DBD ditemukan di semua lokasi ketinggian di antara 3-701 mdpl. Ae. aegypti ditemukan pada ketinggian 218-221 mdpl sedangkan Ae. albopictus ditemukan di ketinggian 839-847 mdpl saja. Pada ketinggian 3-5 mdpl, kepadatan vektor berdasarkan indeks jentik paling tinggi dan pada ketinggian 837-847 mdpl ditemukan paling rendah. Pinontoan (2018) menyatakan Ae. Aegypti sebagai vektor penyakit DBD memiliki kelangsungan hidup yang tinggi pada ketinggian 0-500 mdpl, dan pada ketinggian 1000 mdpl nyamuk Ae.Aegypti idealnya masih bisa bertahan hidup. 


\section{KESIMPULAN}

Sistem Informasi Geografis (SIG) dan metode pemodelan temporal distribusi spasial dapat menampilkan dan memodelkan hubungan spasial antara kasus dan DBD. Pemodelan temporal spasial dapat membantu dalam memahami distribusi DBD dalam ruang dan waktu karena penerapan teknologi SIG sangat baik dalam memvisualkan distribusi temporal dan spasial penyakit berdasarkan determinan ekologi seperti ekologi lanskap, iklim, populasi vektor dan keberadaan serta aktivitas manusia. Model ini dapat digunakan dalam surveilans kesehatan masyarakat dalam untuk kegiatan pengamatan data dan informasi secara sistematis dan berkesinambungan tentang kejadian atau masalah dan kondisi kesehatan yang mempengaruhi terjadinya dan penyebaran kejadian DBD untuk perencanaan, pelaksanaan, dan evaluasi praktik kesehatan masyarakat.

Faktor yang paling berpengaruh terhadap tingkat bahaya DBD adalah hujan tahunan, ketinggian dan kelembaban. Hasil yang diperoleh memperlihatkan bahwa Kabupaten Gorontalo didominasi oleh kelas bahaya seluas $94.852,31$ ha atau $44,25 \%$ dan kelas sedang seluas $82.553,37$ ha atau $38,5 \%$ dari total luas Kabupaten Gorontalo. Hasil ini membuktikan bahwa Kabupaten Gorontalo sangat beresiko terhadap penyakit DBD.

Model prediksi bahaya DBD dengan mempertimbangkan faktor iklim perlu disusun sebagai bentuk upaya mitigasi dalam pengendalian penularan dan pencegahan penyakit DBD. Model prediksi zona bahaya DBD dalam penelitian dapat diaplikasikan berdasarkan kondisi lokal di wilayah penelitian dengan keterbatasan data. Oleh karena itu, model ini dapat digunakan sebagai informasi awal dan peringatan dini oleh pengambil kebijakan dalam merencanakan langkah pengendalian vektor yang efektif untuk menurunkan risiko penularan DBD. Kelemahan dalam penelitian ini adalah (1) keterbatasan dalam memvalidasi distribusi kelas bahaya DBD yang dihasilkan oleh model dengan data sebaran distribusi per kejadian DBD; dan (2) Cakupan wilayah data klimatologi menggunakan basis grid yang sangat luas $\left(0,5^{\circ} \times 0,5^{\circ}\right)$ sehingga variasi distribusi data klimatologi di seluruh wilayah Kabupaten Gorontalo tidak cukup terlihat. Hal ini menyebabkan tingkat validitas data klimatologi untuk per wilayah semakin berkurang.

\section{UCAPAN TERIMA KASIH}

Terimakasih kepada Direktorat Jenderal Penguatan dan Pengembangan Ristekdikti atas bantuan hibah Penelitian Dosen Pemula (PDP) yang diberikan kepada grup peneliti, hingga kegiatan penelitian ini dapat diselesaikan sesuai dengan harapan.

\section{DAFTAR PUSTAKA}

Ajim Ali, S., \& Ahmad, A. (2018). Using analytic hierarchy process with GIS for Dengue risk mapping in Kolkata Municipal Corporation, West Bengal, India. Spatial Information Research, 26(4), 449-469. https:// doi.org/10.1007/s41324-018-0187-x

Amiruddin, M. S. (2016). Pemetaan Tingkat Resiko Wabah Demam Berdarah Dengue (DBD) di Kecamatan Sananwetan, Kota Biltar. Institut Teknologi Sepuluh Nopember Surabaya.

Bhatt, B., \& Joshi, J. P. (2014). Analytical hierarchy process modeling for malaria risk zones in 
vadodara district, Gujarat. International Archives of the Photogrammetry, Remote Sensing and Spatial Information Sciences ISPRS Archives, XL-8(1), 171-176. https:// doi.org/10.5194/isprsarchives-XL-8-1712014

Caldwell, J. M., LaBeaud, A. D., Lambin, E. F., Stewart-Ibarra, A. M., Ndenga, B. A., Mutuku, F. M., Krystosik, A. R., Ayala, E. B., Anyamba, A., Borbor-Cordova, M. J., Damoah, R., Grossi-Soyster, E. N., Heras, F. H., Ngugi, H. N., Ryan, S. J., Shah, M. M., Sippy, R., \& Mordecai, E. A. (2021). Climate predicts geographic and temporal variation in mosquito-borne disease dynamics on two continents. Nature Communications, 12(1), 1-13. https://doi.org/10.1038/s41467021-21496-7

Campbell, L. P., Luther, C., Moo-Llanes, D., Ramsey, J. M., Danis-Lozano, R., \& Peterson, A. T. (2015). Climate change influences on global distributions of dengue and chikungunya virus vectors. Philosophical Transactions of the Royal Society B: Biological Sciences, 370(1665), 1-9. https:// doi.org/10.1098/rstb.2014.0135

Dom, N. C., Ahmad, A. H., Latif, Z. A., \& Ismail, R. (2016). Application of geographical information system-based analytical hierarchy process as a tool for dengue risk assessment. Asian Pacific Journal of Tropical Disease, 6 (12), 928-935. https://doi.org/10.1016/ S2222-1808(16)61158-1

Ewing, D. A., Cobbold, C. A., Purse, B. V., Nunn, M. A., \& White, S. M. (2016). Modelling the effect of temperature on the seasonal population dynamics of temperate mosquitoes. Journal of Theoretical Biology, 400, 65 -79 . https://doi.org/10.1016/ j.jtbi.2016.04.008

Franch-Pardo, I., Napoletano, B. M., Rosete-Verges, F., \& Billa, L. (2020). Spatial analysis and GIS in the study of COVID-19. A review. Science of the Total Environment, 739, 140033. https://doi.org/10.1016/ j.scitotenv.2020.140033

Harapan, H., Michie, A., Mudatsir, M., Sasmono, R. T., \& Imrie, A. (2019). Epidemiology of dengue hemorrhagic fever in Indonesia: Analysis of five decades data from the National Disease Surveillance. BMC Research Notes, 12(1), 4-9. https://doi.org/10.1186/ s13104-019-4379-9
Hendri, J., Santya, R. N. R. ., \& Prasetyowati, H. (2015). Distribusi dan Kepadatan Vektor Demam Berdarah Dengue (DBD) Berdasarkan Ketinggian Tempat di Kabupaten Ciamis Jawa Barat. Jurnal Ekologi Kesehatan, 14(1), 17-28. http:// dx.doi.org/10.22435/jek.v14i1.4654.17-28

Idriani, E., Rahmaniati, M. M., \& Kurniawan, R. (2019). Dengue surveillance information system: An android-based early warning system for the outbreak of Dengue in $\mathrm{Pa}$ dang, Indonesia. Indian Journal of Public Health Research and Development. Indian Journal of Public Health Research and Development, 10(5), 1386-1390. https:// doi.org/10.5958/0976-5506.2019.01124.0

Kementerian Kesehatan RI. (2020). Profil Kesehatan Indonesia Tahun 2019. In Profil Kesehatan Indonesia Tahun 2019. https:// doi.org/10.5005/jp/books/11257_5

Kim, J. Y., Eun, S. J., \& Park, D. K. (2018). Malaria Vulnerability Map Mobile System Development Using GIS-Based Decision-Making Technique. Mobile Information Systems, 2018. https://doi.org/10.1155/2018/8436210

Li, X., Liu, T., Lin, L., Song, T., Du, X., Lin, H., Xiao, J., He, J., Liu, L., Zhu, G., Zeng, W., Guo, L., Cao, Z., Ma, W., \& Zhang, Y. (2017). Application of the analytic hierarchy approach to the risk assessment of Zika virus disease transmission in Guangdong Province, China. BMC Infectious Diseases, 17(1), 1-9. https://doi.org/10.1186/s12879. 016-2170-2

Murad, A. (2018). Using GIS for determining variations in health access in jeddah city, Saudi Arabia. ISPRS International Journal of GeoInformation, 7(7). https://doi.org/10.3390/ ijgi7070254

Murray, N. E. A., Quam, M. B., \& Wilder-Smith, A. (2013). Epidemiology of dengue: Past, present and future prospects. Clinical Epidemiology, 5(1), 299-309. https:// doi.org/10.2147/CLEP.S34440

Musa, G. J., Chiang, P. H., Sylk, T., Bavley, R., Keating, W., Lakew, B., Tsou, H. C., \& Hoven, C. W. (2013). Use of GIS Mapping as a Public Health Tool--From Cholera to Cancer. Health Services Insights, 6, 111116. https://doi.org/10.4137/HSI.S10471

Nakhapakorn, K., \& Tripathi, N. K. (2005). An information value based analysis of physical 
and climatic factors affecting dengue fever and dengue haemorrhagic fever incidence. International Journal of Health Geographics, 4(13), 1-13. https:// doi.org/10.1186/1476-072X-4-13

Nazri Che, D., Abu Hassan, A., Zulkiflee Abd, L., \& Rodziah, I. (2016). Application of geographical information system-based analytical hierarchy process as a tool for dengue risk assessment. Asian Pacific Journal of Tropical Disease, 6(12), 928-935. https:// doi.org/10.1016/S2222-1808(16)61158-1

Nuraini, N., Fauzi, I. S., Fakhruddin, M., Sopaheluwakan, A., \& Soewono, E. (2021). Climatebased dengue model in Semarang, Indonesia: Predictions and descriptive analysis. Infectious Disease Modelling, 6, 598-611. https://doi.org/10.1016/j.idm.2021.03.005

Pinontoan, O. R. (2018). Pengendalian Vektor. Unsrat Press.

Rakotoarison, H. A., Rasamimalala, M., Rakotondramanga, J. M., Ramiranirina, B., Franchard, T., Kapesa, L., Razafindrakoto, J., Guis, H., Tantely, L. M., Girod, R., Rakotoniaina, S., Baril, L., Piola, P., \& Rakotomanana, F. (2020). Remote sensing and multi-criteria evaluation for malaria risk mapping to support indoor residual spraying prioritization in the central highlands of Madagascar. Remote Sensing, 12(10), 1-22. https://doi.org/10.3390/rs12101585

Ramos, L. M. L., Obando, O. A. A., Duque, J. E., \& García-Merchán, V. H. (2020). Effect of altitude on wing metric variation of Aedes aegypti (Diptera: Culicidae) in a region of the Colombian Central Andes. PLOS ONE, 15(8 August), 1-15. https://doi.org/10.1371/ journal.pone. 0228975

Reinhold, J. M., Lazzari, C. R., \& Lahondère, C. (2018). Effects of the environmental temperature on Aedes aegypti and Aedes albopictus mosquitoes: A review. Insects, 9(4). https://doi.org/10.3390/insects9040158

Salim, M. F., \& Syairaji, M. (2020). Time-Series Analysis of Climate Change Effect on Increasing of Dengue Hemorrhagic Fever (DHF) Case with Geographic Information System Approach in Yogyakarta, Indonesia. International Proceedings the 2Ed International Scientific Meeting on Health Information Management, 5, 248-256. https:// www.publikasi.aptirmik.or.id/index.php/ ismohim2020/article/view/142/

Saran, S., Singh, P., Kumar, V., \& Chauhan, P. (2020). Review of Geospatial Technology for Infectious Disease Surveillance: Use Case on COVID-19. Journal of the Indian Society of Remote Sensing, 48(8), 11211138. https://doi.org/10.1007/s12524-02001140-5

Stocker, T. F., Qin, D., Plattner, G. K., Tignor, M. B., Allen, S., Boschung, J., Nauels, A., Xia, Y., Bex, V., \& Midgley, P. M. (2013). Climate change 2013 the physical science basis: Working Group I contribution to the fifth assessment report of the intergovernmental panel on climate change. In Climate Change 2013 the Physical Science Basis: Working Group I Contribution to the Fifth Assessment Report of the Intergovernmental Panel on Climate Change (Vol. 5). https:// doi.org/10.1017/CBO9781107415324

Sulekan, A., Suhaila, J., \& Wahid, N. A. A. (2021). Assessing the Effect of Climate Factors on Dengue Incidence via a Generalized Linear Model. Open Journal of Applied Sciences, 10(04), 549-563. https://doi.org/10.4236/ ojapps.2021.104039

Sulistyawati, S. (2020). Measuring the dengue risk area using Geographic Information System: a review. Insights in Public Health Journal, 1(1), $36 . \quad \mathrm{https}: / /$ doi.org/10.20884/1.iphj.2020.1.1.3012

Tamengkel, H. V., Sumampouw, O. J., \& Pinontoan, O. R. (2020). Ketinggian Tempat Dan Kejadian Demam Berdarah Dengue. Indonesian Journal Of Public Health and Community Medicine, 1(1), 12-18. https:// doi.org/10.35801/ijphcm.1.1.2020.26642

Tjaden, N. B., Thomas, S. M., Fischer, D., \& Beierkuhnlein, C. (2013). Extrinsic Incubation Period of Dengue: Knowledge, Backlog, and Applications of Temperature Dependence. PLoS Neglected Tropical Diseases, 7(6), 15. journal.pntd.0002207 https://doi.org/10.1371/

Tran, A., L’Ambert, G., Lacour, G., Benoît, R., Demarchi, M., Cros, M., Cailly, P., AubryKientz, M., Balenghien, T., \& Ezanno, P. (2013). A rainfall- and temperature-driven abundance model for Aedes albopictus populations. International Journal of Environmental Research and Public Health, 10(5), 1698-1719. https://doi.org/10.3390/ 
ijerph10051698

Tsheten, T., Clements, A. C. A., Gray, D. J., \& Wangdi, K. (2021). Dengue risk assessment using multicriteria decision analysis: A case study of Bhutan. PLoS Neglected Tropical Diseases, 15(2), 1-17. https:// doi.org/10.1371/journal.pntd.0009021

Verdonschot, P. F. M., \& Besse-Lototskaya, A. A. (2014). Flight distance of mosquitoes (Culicidae): A metadata analysis to support the management of barrier zones around rewetted and newly constructed wetlands. Limnologica, 45, 69-79. https:// doi.org/10.1016/j.limno.2013.11.002

WHO Regional Publication SEARO. (2011). Comprehensive guidelines for prevention and control of dengue and dengue haemorrhagic fever. In WHO Regional Publication SEARO (Issue 1). https://apps.who.int/iris/ handle/10665/204894

WHO. (2018). Managing Epidemics, Key facts about major deadly diseases. https://www.who.int/ emergencies/diseases/managing-epidemics/ en/

Xu, L., Stige, L. C., Chan, K. S., Zhou, J., Yang, J., Sang, S., Wang, M., Yang, Z., Yan, Z., Jiang, T., Lu, L., Yue, Y., Liu, X., Lin, H., Xu, J., Liu, Q., \& Stenseth, N. C. (2017). Climate variation drives dengue dynamics. Proceedings of the National Academy of Sciences of the United States of America, 114(1), 113-118. https://doi.org/10.1073/ pnas. 1618558114 